\title{
Implementasi Metode SAW dalam Memilih Software Manajemen Bisnis dan Keuangan
}

\author{
Narti $^{1}$, Fatmawati $^{2}$ \\ ${ }^{1}$ Sistem Informasi, Universitas Nusa Mandiri \\ Indonesia \\ ${ }^{2}$ Sistem Informasi, Universitas Nusa Mandiri \\ Indonesia \\ *Corresponding Author.E-mail:narti.nrx@nusamandiri.ac.id, \\ fatmawati.fmw@nusamandiri.ac.id
}

\begin{abstract}
Abstrak
Penelitian ini dilakukan agar penulis dapat memecahkan masalah yang ada pada sebuah perusahaan yang ada di kota Tangerang ${ }_{2}$ perusahaan tersebut membutuhkan sebuah aplikasi atau software manajemen bisnis dan keuangan yang dapat membantu pencatatan keuangan perusahaan tersebut. Tujuan dari dilakukannya penelitian ini untuk menemukan software manajemen bisnis dan keuangan yang paling mudah dan banyak peminatnya untuk digunakan sehingga bisa membantu perusahaan memilihkan software. Dalam membantu perusahaan tersebut, penulis mencoba menggunakan sebuah model/ metode sistem penunjang keputusan yang mampu membantu perusahaan untuk memilihkan software manajemen bisnis dan keuangan. Metode tersebut adalah Simple Additive Weighting (SAW). Dalam penelitian ini penulis mencoba membandingkan tiga buah software manajemen bisnis dan keuangan yaitu SAP, Zahir dan Limax sebagai alternatif pembanding. Peneliti menggunakan empat kriteria yaitu harga, fleksibilitas, fasilitas, efesien maka ditemukan salah satu software manajemen bisnis dan keuangan yang memiliki hasil perangkingan terbaik yaitu Zahir.
\end{abstract}

Kata Kunci: SPK; SAW; Aplikasi Keuangan

\begin{abstract}
This research was conducted so that the author can solve the problems that exist in a company in the city of Tangerang, the company requires an application or business and financial management software that can help the company's financial records. The purpose of this research is to find the easiest and most popular business and financial management software to use so that it can help companies choose software. In helping the company, the author tries to use a decision support system model/method that can help companies to choose business and financial management software. The method is Simple Additive Weighting (SAW). In this study, the author tries to compare three business and financial management software, namely SAP, Zahir and Limax as an alternative comparison. Researchers used four criteria, namely price, flexibility, facilities, efficiency, so it was found that one of the business and financial management software that has the best ranking results is Zahir..
\end{abstract}

Keywords: SPK; SAW; accounting software

\section{Introduction}

Adanya penelitian ini didasari oleh adanya masalah yang dihadapi oleh sebuah perusahaan menengah di kota Tangerang, perusahaan tersebut mengalami kesulitan dalam memilih sebuah aplikasi manajemen 
bisnis dan keuangan, perusahaan tersebut ingin menggunakan software untuk membantu pencatatan keuangan perusahaannya, sebelumnya perusahaan tersebut masih melakukan mencatatan secara konvensional sehingga perusahaan tersebut mengalami kesulitan dalam membuat laporan keuangan.

Atas dasar itulah perusahaan tersebut menginginkan sebuah software manajemen bisnis dan keuangan yang dapat membantu dalam pencatatan keuangan perusahaan, namun di sisi lain perusahaan menghadapi kesulitan dalam memilih software tersebut, manakah yang lebih murah, efesien, dan efektif.

Peneliti mencoba menerapkan sebuah metode penunjang keputusan yaitu Simple Additive Weighting (SAW) yang diharapkan mampu menunjukan hasil software yang terbaik.

Metode SAW ini mempunyai konsep dimana mencari penjumlahan dengan nilai yang berkualitas dari alternatif terhadap setiap atribut yang ada. (Wicaksono \& Santoso, 2020)

Dalam penelitian ini, peneliti melakukan pemilihan software manajemen bisnis dan keuangan dengan tiga alternatif dan empat kriteria pembanding, adapun alterrnatifnya adalah software SAP, Zahir dan Limax serta empat kriteria pembandingnya yaitu harga, fleksibelitss, fasilitas, efesien.
Pada penelitian sebelumnya yang dilakukan oleh Adityo Putro Wicaksono dan Albert Santoso mereka berhasil menggunakan metode SAW untuk mengambil keputusan dalam memilih smartphone, dalam penelitian ini kebaruannya adalah penulis menggunakan metode SAW untuk membantu perusahaan dalam memilih aplikasi manajemen bisnis dan keuangan.

\section{Materials and Methods}

\subsection{Metode SAW}

Kusumadewi mengatakan bahwa Metode Simple Additive Weighting juga sering dikenal dengan istilah metode penjumlahan terbobot. (Kusumadewi, 2006)

MMetode SAW diklaim sebagai metode paling terkenal dan paling banyak digunakan dalam menghadapi situasi Multiple Attribute Decision Making (MADM). (Hermanto \& Izzah, 2018)

Metode SAW umumnya dianggap sebagai metode yang paling sederhana dan paling intuitif untuk menangani masalah pengambilan keputusan multi-kriteria (MCDM). (Turban \& Aronson, 2001)

metode ini adalah metode penghitungan tertimbang atau metode yang menyediakan kriteria tertentu yang berbobot sehingga setiap nilai jumlah dari bobot dari hasil yang diperoleh akan menjadi keputusan akhir.(Frieyadie, 2016)

Konsep dasar metode SAW adalah mencari penjumlahan terbobot dari rating kinerja pada setiap alternatif pada semua 
atribut.(Ridhawati, Siregar, \& Iriawan, 2018)

Multi Attribute Decision Making penunjang pengambilan metode merupakan suatu keputusan yang DeCriteria Multiple cision Making untuk yang digunakan (MCDM) memecahkan permasalahan dalam ruang diskrit. (Resti, 2017)

Dengan metode yang mencari penjumlahan terbobot dari rating kinerja pada setiap alternatif pada semua atribut. Metode ini membutuhkan normalisasi dengan rumus seperti dibawah ini. (Christioko, Indriyawati, \& Hidayati, 2017)

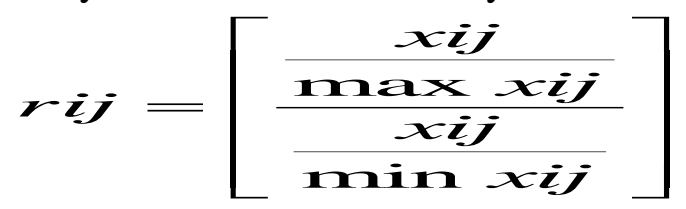

rij merupakan rating kinerja ternormalisasi dari alternative, Ai pada atribut $\mathrm{Cj}$, dimana $\mathrm{i}=1,2, \ldots \mathrm{m}$ dan $\mathrm{j}=1,2, \ldots, \mathrm{n}$. Nilai preferensi untuk setiap alternatif(Vi) diberikan sebagai berikut:

$V i=\sum_{j}^{n}=1 w j r j$

Nilai (Vi) yang lebih besar mengindikasikan bahwa alternative $\mathrm{Ai}$ lebih terpilih.(Christioko et al., 2017)

Metode SAW dipilih karena dapat menentukan nilai bobot untuk setiap atribut, kemudian dilanjutkan dengan proses perankingan yang akan menyeleksi alternatif terbaik dari sejumlah alternative.(Muhammad, Safriadi, \& Prihartini, 2017)

SAW digunakan karena dapat memberikan hasil akurat sehingga dapat dijadikan sebagai alat bantu dalam proses pengambilan keputusan.(Harsiti \& Aprianti, 2017)

\subsection{Sistem Informasi Akuntansi / Software Manajemen Bisnis Dan Keuangan}

Sistem Informasi Akuntansi / Software Manajemen Bisnis Dan Keuangan sangat penting bagi sebuah perusahan karena dapat membantu dalam mencatat transaksi keuangan guna mendapatkan informasi laporan keuangan.

Akuntansi adalah kegiatan mengidentifikasi, menghimpun, memproses, dan mengkomunikasikan informasi ekonomi khususnya keuangan suatu organisasi bisnis.(Musmini, 2013)

Sistem informasi akuntansi (SIA) merupakan gabungan dari tiga kata, yaitu sistem, informasi dan akuntansi.(Efendi, Indrian Supheni, \& Astutik, 2013)

Dalam bukunya Azhar Susanto, ia mengatakan bahwa organisasi-organisasi jadi sangat ketergantungan terhadap system informasi (SIA) karena peran informasi yang begitu tinggi serta perlunya mereka informasi sebagai sumberdaya yang sangat berharga untuk menghindari resiko sehingga turut menentukan bisa tidaknya suatu organisasi terus beroperasi.(Susanto, 2017)

Sistem informasi akuntansi adalah suatu komponen yang mengumpulkan, menggolongkan, mengolah, menganalisa, dan mengkombinasikan informasi keuangan yang relevan untuk pengambilan keputusan pihak-pihak luar (seperti pemerintah, masyarakat, investor, dan kreditor) pihak- 
pihak dalam (terutama manajemen). (Otinur, Pangemanan, \& Warongan, 2017)

Sistem informasi akuntansi adalah : sistem akuntansi berbasis komputerisasi yang mengolah data keuangan yang berhubungan dengan data transaksi dalam siklus akuntansi dan menyajikannya dalam bentuk laporan keuangan kepada manajemen perusahaan.(Jaya, 2018)

Dari hal pentingnya bagi sebuah perusahaan untuk memilih software manajemen bisnis dan keuangan yang tepat untuk membantu memanajemen keuangan perusahaan maka penulis ingin melakukan penelitian memilih software manajemen bisnis dan keuangan dengan menggunakan metode SAW, berikut beberapa kriteria yang digunakan dan beberapa alternatif yang akan dijadikan objek pilihan.

Table 1. Kriteria

\begin{tabular}{cc}
\hline Kriteria & Keterangan \\
\hline C1 & Harga \\
C2 & Fleksibelitas \\
C3 & Fasilitas \\
C4 & Efesien \\
\hline
\end{tabular}

Sumber: Pengolahan data penelitian

Table 2. Alternatif

\begin{tabular}{cc}
\hline Alternatif & Keterangan \\
\hline A1 & SAP \\
A2 & Zahir \\
A3 & Limax \\
\hline
\end{tabular}

Sumber: Pengolahan data penelitian

\section{Results and Discussion}

Penelitian ini didasari oleh pentingnya bagi setiap instansi/ perusahaan dalam memilih software manajemen bisnis dan keuangan yang tepat. Metode Simple Additive Weighting (SAW) dalam per perhitungannya perlu beberapa kriteria serta bobot, sehingga akan memperoleh hasil untuk menentukan alternative yang terbaik dalam memilih software manajemen bisnis dan keuangan yang tepat bedasarkan perhitungan menggunakan system pendukung keputusan metode SAW. Pada penelitian ini peneliti mengambil 3 buah alternatif dan 4 buah kriteria. Alternatif tersebut ialah SAP, Zahir dan Limax dan kriteria-kriterianya antara lain harga, fleksibelitas, fasilitas, efesien.

\subsection{Pembobotan setiap Kriteria}

Berikut adalah table pembobotan setiap kriteria untuk menentukan nilai-nilai yang akan dibuat berdasarkan keterangan masingmasing.

Table 3. Criteria Harga

\begin{tabular}{cc}
\hline Harga & Nilai \\
\hline <1 Juta & 5 \\
1,5 Juta - 3 Juta & 4 \\
3,5 Juta - 5 Juta & 3 \\
5,5 Juta - 10 Juta & 2 \\
$>15$ Juta & 1 \\
\hline
\end{tabular}

Sumber: Pengolahan data penelitian

Table 4. Criteria Fleksibelitas

\begin{tabular}{cc}
\hline Fleksibelitas & Nilai \\
\hline Sangat Simple & 5 \\
Simple & 4 \\
Cukup Sulit & 3 \\
Membingungkan & 2 \\
Sangat Membingungkan & 1 \\
\hline
\end{tabular}

Sumber: Pengolahan data penelitian 
Table 5. Criteria Fasilitas

\begin{tabular}{cc}
\hline Fasilitas & Nilai \\
\hline Sangat Lengkap & 5 \\
Cukup Lengkap & 4 \\
Kurang Lengkap & 3 \\
Tidak Lengkap & 2 \\
\hline
\end{tabular}

Sumber: Pengolahan data penelitian

Table 6. Criteria Efesien

\begin{tabular}{cc}
\hline Efesien & Nilai \\
\hline Sangat Efesien & 5 \\
Cukup Efesien & 4 \\
Kurang Efesien & 3 \\
Tidak Efesien & 2 \\
\hline
\end{tabular}

Sumber: Pengolahan data penelitian

\subsection{Bobot Preferensi(W)}

Selanjutnya adalah mencari bobot preferensi atau tingkat kepentingan tiap kriteria. Berikut adalah table bobot preferensi (W):

Table 7. Pembobotan

\begin{tabular}{|c|c|c|c|c|}
\hline Kode & Kriteria & Bobot & $\begin{array}{c}\text { Bobot } \\
\text { W }\end{array}$ & $\begin{array}{l}\text { Bilangan } \\
\text { Fuzzy }\end{array}$ \\
\hline $\mathrm{C} 1$ & Harga & $50 \%$ & 0,50 & $\begin{array}{l}\text { Sangat } \\
\text { Tinggi } \\
\text { (ST) }\end{array}$ \\
\hline $\mathrm{C} 2$ & Fleksibelitas & $25 \%$ & 0,25 & $\begin{array}{l}\text { Sangat } \\
\text { Rendah } \\
\text { (SR) }\end{array}$ \\
\hline $\mathrm{C} 3$ & Fasilitas & $15 \%$ & 0,15 & $\begin{array}{l}\text { Cukup } \\
\text { (C) }\end{array}$ \\
\hline $\mathrm{C} 4$ & Efisien & $10 \%$ & 0,10 & $\begin{array}{l}\text { Cukup } \\
\text { (C) }\end{array}$ \\
\hline
\end{tabular}

Sumber: Pengolahan data Penelitian

Dari hasil perhitungan pembobotan diatas maka didapatlah bobot (W) dibawah ini:

\subsection{Rating Nilai Kecocokan pada tiap}

\section{Criteria pada Alternatif}

Yang berikutnya adalah menentukan nilai rating kecocokan dari setiap criteria terhadap alternatif-alternatif, berikut adalah tabelnnya:

Table 8. Rating Nilai

\begin{tabular}{lllll}
\hline \multirow{2}{*}{ Alternatif } & \multicolumn{4}{c}{ Criteria } \\
\cline { 2 - 5 } & $\mathrm{C} 1$ & $\mathrm{C} 2$ & $\mathrm{C} 3$ & $\mathrm{C} 4$ \\
SAP & 2 & 5 & 5 & 5 \\
Zahir & 4 & 5 & 4 & 4 \\
Limax & 2 & 4 & 5 & 5 \\
\hline
\end{tabular}

Sumber: Pengolahan data penelitian

\subsection{Matriks Keputusan}

Selanjutnya ialah membuat matriks keputusan $(\mathrm{X})$, berikut adalah hasil dari pembuatan matriks yang terbentuk dari table nilai rating kecocokan pada setiap alternatif terhadap setiap criteria, berikut matriksnya:

$$
x=\left[\begin{array}{llll}
2 & 5 & 5 & 5 \\
4 & 5 & 4 & 4 \\
2 & 4 & 5 & 3
\end{array}\right]
$$

\subsection{Normalisasi Matriks Keputusan (X) \\ Berikutnya dilakukan proses normalisasi} matriks keputusan ke sebuah skala perbandingan yang nanti dibandingkan dengan semua nilai rating alternative. Berikut rumusnya:

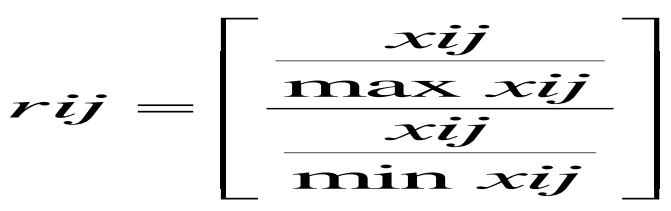

Dimana :

rij $=$ rating kinerja ternormalisasi

Maxij = nilai Maximal baris dan kolom 
Minij = nilai minimum dari setiap baris dan kolom

$\mathrm{Xij}=$ baris dan kolom dari matriks

$$
\begin{gathered}
\text { Criteria Harga (Cost) } \\
\begin{array}{l}
\mathrm{R} 11=2 / 2=1 \\
\mathrm{R} 12=4 / 2=2 \\
\mathrm{R} 13=2 / 2=1
\end{array}
\end{gathered}
$$

\section{Criteria Fleksibelitas (Benefit)}

$$
\begin{aligned}
& \mathrm{R} 21=5 / 5=1 \\
& \mathrm{R} 22=5 / 5=1 \\
& \mathrm{R} 23=4 / 5=0,8
\end{aligned}
$$

Criteria Fasilitas (Benefit)

$$
\begin{aligned}
& \mathrm{R} 31=5 / 5=1 \\
& \mathrm{R} 32=4 / 5=0,8 \\
& \mathrm{R} 33=5 / 5=1
\end{aligned}
$$

\section{Criteria Efesien (Benefit)}

$$
\begin{aligned}
& \mathrm{R} 41=5 / 5=1 \\
& \mathrm{R} 42=4 / 5=0,8 \\
& \mathrm{R} 43=3 / 5=0,6
\end{aligned}
$$

Selanjutnya adalah proses Factor ternormalisasi dimana dimasukan semua hasil perhitungan kedalam tabel. Berikut adalah matriks ternormalisasi:

$$
x=\left[\begin{array}{cccc}
1 & 1 & 1 & 1 \\
2 & 1 & 0.8 & 0.8 \\
1 & 0.8 & 1 & 0.6
\end{array}\right]
$$

Selanjut-nya terbentuk-lah table ternotmalisasi sebagai berikut.

Table 9. Matriks Ternormalisasi

\begin{tabular}{llll}
\hline 1 & 1 & 1 & 1 \\
2 & 1 & 0,8 & 0,8 \\
1 & 0,8 & 1 & 0,6 \\
\hline
\end{tabular}

\subsection{Perangkingan}

Hal ini adalah langkah terakhir dalam perhitungan pada metode SAW yakni menghitung hasil dari nilai preferensi yang didapat dari penjumlahan dan perkalian, berikut adalah hasilnya:

$$
\begin{aligned}
& \mathrm{R} 1=(1 * 0,50)+(1 * 0,25)+(1 * 0,15)+(1 * 0,10) \\
& \mathrm{R} 1=1 \\
& \mathrm{R} 2=(2 * 0,50)+(1 * 0,25)+(0,8 * 0,15)+(0,8 * \\
& 0,10) \\
& \mathrm{R} 2=1,45 \\
& \mathrm{R} 3=(1 * 0,50)+(0,8 * 0,25)+(1 * 0,15)+(0,6 * \\
& 0,10) \\
& \mathrm{R} 3=0,66 \\
& \text { Berikut ini adalah table hasil perhitungan } \\
& \text { menggunakan ms. Excel }
\end{aligned}
$$

Table 10. Hasil Pemeringkatan/ Perangkingan

\begin{tabular}{cccccc}
\hline & C1 & C2 & C3 & C4 & HASIL \\
\hline SAP & 0,50 & 0,25 & 0,15 & 0,10 & 1,00 \\
ZAHIR & 1,00 & 0,25 & 0,12 & 0,08 & 1,45 \\
LIMAX & 0,25 & 0,20 & 0,15 & 0,06 & 0,66 \\
\hline
\end{tabular}

\section{Conclusions}

Dalam penelitian ini telah didapat hasil pemilihan software manajemen bisnis dan keuangan dengan menggunakan sebuah metode penunjang keputusan yaitu SAW, Dimana ditemukan alternatif dengan hasil nilai tertinggi yaitu software Zahir dengan nilai 1,45. Pada penelitian ini terdapat beberapa kekurangan yaitu penggunaan 
alternatif hanya 3 pilihan, disarankan untuk peneliti selanjutnya bisa menambahkan alternatif pilihan dan menambah kriteria serta bisa juga mengaplikasikan metode lain yang mungkin lebih tepat. Penelitian ini berhasil membantu perusahaan dalam menemukan software yang dibutuhkan.

\section{Acknowledgments}

Pada penelitian ini, peneliti ingin menyampaikan rasa terimakasih yang sebesar-besarnya kepada pihak-pihak yang terkait dalam penelitian ini, diantaranya ibu Fatmawati selaku penulis ke dua yang telah membantu dalam penyusunan penelitian ini, tak lupa kepada para pemilik jurnal dan buku yang ilmunya saya gunakan dalam penelitian ini, juga kepada Publisher LPPM UBSI, Tim redaksi serta kepada ibu Ina Maryani dan Ibu Eva Argarini P selaku Editor Jurnal.

\section{References}

Christioko, b. V., indriyawati, h., \& hidayati, n. (2017). Fuzzy multiatribute decision making (fuzzy madm) dengan metode saw untuk pemilihan mahasiswa berprestasi, 14(2), 82-85. Retrieved

from https://www.researchgate.net/publicati on/321258211_fuzzy_multi-

atribute_decision_making_fuzzy_mad m_dengan_metode_saw_untuk_pemili han_mahasiswa_berprestasi
Efendi, d., indrian supheni, \& astutik, r. W. (2013). Pengaruh sistem informasi akuntansi dan kinerja karyawan terhadap keefektifan pengendalian internal di koperindo jatim cabang nganjuk. Cahaya aktiva, 3(2), 72-81.

Retrieved from https://www.cahayasurya.ac.id/jurnal/fi le/artikel 1.pdf

Frieyadie. (2016). Penerapan metode simple additive weight (saw) dalam sistem pendukung keputusan promosi kenaikan jabatan. Jurnal pilar nusa mandiri, xii(1), 37-45. Retrieved from https://ejournal.nusamandiri.ac.id/inde x.php/pilar/article/view/257

Harsiti, \& aprianti, h. (2017). Sistem pendukung keputusan pemilihan smartphone dengan menerapkan metode simple additive weighting (saw). Jurnal sistem informasi, 4(1), 19-24. Retrieved from https://ejurnal.lppmunsera.org/index.php/jsii/ar ticle/view/372

Hermanto, \& izzah, n. (2018). Sistem pendukung keputusan pemilihan motor dengan metode simple additive weighting (saw), 6(2), 184-200. Retrieved from https://doi.org/10.33477/mp.v6i2.669

Jaya, h. (2018). Analisis sistem informasi 
akuntansi penjualan dan penerimaan kas dalam meningkatkan pengendalian intern. Measurement, 12(2), 152-167. Retrieved from https://www.journal.unrika.ac.id/index. php/measurement/article/view/1741

Kusumadewi, s. (2006). Fuzzy multiattribute decision making (fmadm). Jogjakarta: graha. Retrieved from https://www.repository.uinjkt.ac.id/dsp ace/bitstream/123456789/30275/1/ach mad akrom-fst.pdf

Muhammad, m., safriadi, n., \& prihartini, n. (2017). Implementasi metode simple additive weighting(saw) pada sistem pendukung keputusan dalam menentukan prioritas perbaikan jalan. Jurnal sistem dan teknologi informasi, 5(4), 223-228. Retrieved from https://core.ac.uk/download/pdf/29644 1645.pdf

Musmini, 1. S. (2013). Sistem informasi akuntansi untuk menunjang pemberdayaan pengelolaan usaha kecil. Vokasi jurnal riset akuntansi, 2(1), 62-81. Retrieved from https://ejournal.undiksha.ac.id/index.ph p/jjakun/article/view/1064

Otinur, f., pangemanan, s. S., \& warongan, j. (2017). Analisis sistem informasi akuntansi dan sistem pengendalian internal persediaan barang pada toko campladean manado. Jurnal riset akuntansi going concern, 12(1), 169179. Retrieved from https://ejournal.unsrat.ac.id/index.php/ gc/article/view/17202

Resti, n. C. (2017). Penerapan metode simple additive weighting (saw) pada sistem pendukung keputusan pemilihan lokasi untuk cabang baru toko pakan ud. Indo multi fish, 1(2), 102-107. Retrieved from https://doi.org/10.29407/intensif.v1i2.8 39

Ridhawati, e., siregar, g. K., \& iriawan, d. (2018). Metode simple additive weighting (saw) pada sistem pendukung keputusan penilai kinerja guru (pkg) (studi kasus smp $17 \quad 1$ pagelaran) eka. Jurnal informasi dan komputer, 6(2), 38-49. Retrieved from https://www.neliti.com/id/publications/ 273809/metode-simple-additiveweighting-saw-pada-sistempendukung-keputusan-penilai-kin

Susanto, a. (2017). Sistem informasi akuntansi (perdana). Bandung: lingga jaya. Retrieved from https://te.1lib.limited/book/11623849/6 d4662

Turban, e., \& aronson, j. E. (2001). 


$\begin{array}{lcccc}\text { Decision support systems and } & \text { Wicaksono, a. P., \& santoso, a. (2020). } \\ \text { intelligent systems 6th edition (6th } & \text { Sistem } & \text { rekomendasi } & \text { pemilihan } \\ \text { editio). Prentice hall. Retrieved from } & \text { smartphone android dengan dana } \\ \text { https://www.academia.edu/11191200/t } & \text { terbatas menggunakan modified simple } \\ \text { urban_efraim_and_jay_e_aronson_deci } & \text { additive weighting (m-saw), } & \text { 17(2), } \\ \text { sion_support_systems_and_intelligent_ } & \text { 115-123. } & \text { Retrieved } & \text { from } \\ \text { systems_prentice_hall_upper_saddle_ri } & \text { https://journals.usm.ac.id/index.php/tra } \\ \text { ver_nj_1998 } & \text { nsformatika/article/view/1561 }\end{array}$

